\title{
Incidence of falls in a cohort of critical adults: a cause for concerns?
}

\author{
Incidência de quedas em uma coorte de adultos críticos: \\ motivo de preocupação?
}

Incidencia de caídas en una cohorte de adultos críticos:

¿motivo de preocupación?

\author{
Andréia Martins Specht ${ }^{\mathrm{a}}$ \\ Gabriele Peres de Sousab \\ Mariur Gomes Beghetto ${ }^{c}$
}

\section{How to cite this article:} Specht AM, Sousa GP, Beghetto MG. Incidence of falls in a cohort of critical adults: a cause for concerns? Rev Gaúcha Enferm. 2020;41(esp):e20190167. doi: https://doi.org/10.1590/19831447.2020.20190167 a Universidade Federal do Rio Grande do Sul (UFRGS), Escola de Enfermagem. Porto Alegre, Rio Grande do Sul, Brasil.

b Universidade Federal do Rio Grande do Sul (UFRGS), Escola de Enfermagem, Curso de Graduação em Enfermagem. Porto Alegre, Rio Grande do Sul, Brasil.

Universidade Federal do Rio Grande do Sul (UFRGS), Escola de Enfermagem. Departamento de Assistência e Orientação Profissional. Porto Alegre, Rio Grande do Sul, Brasil.

\section{ABSTRACT}

Objective: To describe the incidence and to report the cases of falls in a cohort of critical adults.

Method: A prospective cohort study, conducted in 2018 at an adult Intensive Care Unit (ICU) in the south of Brazil. The patients were followed up from admission to discharge; observations were made in the morning and afternoon. The clinical and care variables were evaluated. The descriptive analysis was performed followed by the reporting of the cases.

Results: 551 patients were monitored during 6 [3-12.7] days of hospitalization, generating 7,839 observations. There were four cases of falls, with an incidence rate of 5.1/10.000 observations/day - confidence interval of $99 \%$ [0.9 to 16] and density of incidence of $7 / 10.000$ observations/day - confidence interval of $99 \%$ [1.2 to 22]. No serious harms were observed.

Conclusion: Falls occur less in the ICU, which can be explained by the use of safe care practices.

Keywords: Accidental falls. Critical care. Intensive care units. Patient safety. Accidents.

\section{RESUMO}

Objetivo: Descrever a incidência e relatar os casos de quedas em uma coorte de adultos críticos.

Método: Estudo de coorte prospectivo, realizado em 2018 em Unidade de Terapia Intensiva (UTI) adulto no sul do Brasil. Pacientes foram acompanhados da admissão até a alta; as observações foram realizadas mais de uma vez ao dia. Foram avaliadas variáveis clínicas e de cuidados. Foi realizada análise descritiva, seguida do relato dos casos.

Resultados: Foram acompanhados 551 pacientes, por 6 [3 - 12,7] dias de internação, gerando 7.839 observações. Houve quatro casos de quedas, com taxa de incidência de 5,1/10.000 observações/dia - intervalo de confiança de 99\% [0,9 a 16] e densidade de incidência de 7/10.000 observações/dia - intervalo de confiança de $99 \%$ [1,2 a 22]. Não foi observado dano grave.

Conclusão: Quedas são pouco incidentes em UTI, o que pode ser explicado pelo emprego de práticas assistenciais seguras.

Palavras-chave: Acidentes por quedas. Cuidados críticos. Unidades de terapia intensiva. Segurança do paciente. Acidentes.

\section{RESUMEN}

Objetivo: Describir la incidencia y relatar los casos de caídas en una cohorte de adultos críticos.

Método: Estudio de cohorte prospectivo, realizado en 2018 en una Unidad de Cuidados Intensivos (UCI) para adultos en el sur de Brasil. A los pacientes se les realizó un seguimiento desde la admisión hasta el alta; las observaciones se realizaron por la mañana y por la tarde. Se evaluaron variables clínicas y de cuidados. Se llevó a cabo un análisis descriptivo, seguido del informe de los casos.

Resultados: Se realizó un seguimiento a 551 pacientes, durante 6 [3 - 12,7] días de internación, con lo cual se generaron 7.839 observaciones. Se observaron cuatro casos de caídas, con una tasa de incidencia de 5,1/10.000 observaciones por día - intervalo de confianza del $99 \%$ [0,9 a 16] y densidad de incidencia de 7/10.000 observaciones por día - intervalo de confianza del 99\% [1,2 a 22]. No se observó ningún daño grave.

Conclusión: No se registra gran incidencia de caídas en la UCl, lo que puede explicarse por el empleo de prácticas asistenciales seguras.

Palabras clave: Accidentes por caídas. Cuidados críticos. Unidades de cuidados intensivos. Seguridad del paciente. Accidentes. 


\section{口INTRODUCTION}

A hospital fall is defined by the Ministry of Health as unintentional displacement of the body below the initial position, caused by multi-factorial circumstances and whether or not resulting in harm ${ }^{(1)}$. Its incidence is estimated to be between $3.7 / 1,000$ patient-day ${ }^{(2)}$ and 4.8/1,000 patient-day ${ }^{(3)}$, varying due to the differences in the profile of evaluated patients and institutions ${ }^{(4)}$.

It is associated with different patient-related factors (limitation of walking, unaccompanied, anticoagulant use, sedative use, decreased strength, slipping, dizziness, confusion, tripping, fainting, and seizure) and environment (equipment failure, wetness, no bed railing, poor lighting, obstacle and freshly waxed floor) $)^{(5)}$.

Falls can cause transient or permanent harm with varying magnitude. A multi-center study showed that 30\% to 50\% of the falls result in some form of harm; of these, $6 \%$ to $44 \%$ are considered serious damage such as fractures, bruises and bleeding. ${ }^{(4)} \mathrm{A}$ similar incidence of falls resulting in harm (30.7\%) was documented in a unicenter cross-sectional study. In this study, the need for clinical intervention was identified due to the fall in $3.4 \%$ of the cases ${ }^{(5)}$.

The main goal of researchers and practitioners is to early identify at-risk patients in order to settle protective measures. In this sense, scales to assess the risk of falls have been proposed since 1985(6). The Morse Fall Scale (1989) was developed for hospitalized clinical patients ${ }^{(7)}$ and was translated and adapted for use in Brazil in 2013 ${ }^{(8)}$. It consists of six domains and its score ranges from zero to 125; the higher the score, the higher is the risk of falling ${ }^{(7)}$. Although the Morse Scale is widely used to estimate the risk of falls from different profiles of hospitalized patients, including ICU patients, the authors of the original study recommend that the scale be locally calibrated so that the prevention strategies are directed to patients with a higher risk ${ }^{(7)}$. They emphasize that the risk of falling varies according to the type of patient, at different times of the day and in the situations to which the patient is exposed ${ }^{(9)}$. A critical patient, for example, easily scores high. Thus, in the practice of the ICUs, the scale seems to contribute little, since the same protection barriers are employed for all patients, despite the score achieved; that is, it does not withdraw, or adds fall protection measures according to the score.

A recent systematic review has shown that studies related to falls in intensive care units (ICUs) are limited; among the eight studies that approach adverse events in the ICUs, just one referred to the fall outcome ${ }^{(10)}$. In fact, the studies on falls in hospitals are restricted to other areas of hospitalization, promoting a knowledge gap. For example, with the justification that the dynamics of the ICUs differs from the others, a multi-center study that was dedicated to evaluate the relation between number of nursing staff and the incidence of falls in US hospitals excluded ICU patients from the analysis ${ }^{(3)}$.

The scarce studies on falls are restricted to a few observations, employing poorly designed statistical designs and analyzes ${ }^{(11)}$. Examples of this are a retrospective article in a hospital in Minas Gerais, Brazil, aimed at assessing factors associated with the risk of falls in patients undergoing surgical procedures, which described 67 events ${ }^{(12)}$. Another example is a case-control study conducted in southern Brazil to identify predictors of falls in hospitalized adult patients in 12 surgical units with 843 beds, which is limited to describing 358 falls in 18 months ${ }^{(13)}$.

Additionally, the occurrence of falls in the ICU may lead to feelings of guilt, impotence and negligence in the professionals, as described in an article published in Maringá, in $2002^{(11)}$. In this sense, the aim of this study is to describe the incidence and factors associated with falls in a cohort of critical adults.

\section{DETHOD}

This is a study from the doctoral dissertation project entitled "Safety in mobilization in a cohort of adults admitted to an intensive care unit". A prospective cohort of adults (age $\geq 18$ years old) who were admitted to an Intensive Care Unit (ICU) of a large public hospital in southern Brazil from June to November 2018 was conducted. The study included patients whose length of stay was less than 36 hours, under palliative care, multiple trauma, under cerebrospinal fluid drainage, neuromuscular disease, unconsolidated fracture and pregnant women. The patients were consecutively included and were followed by previously trained nurses and undergraduate nursing students. For all the patients, the same data collect instrument developed by the authors was used. The data collect instrument included sociodemographic variables, past and current health history, therapies and interventions instituted, clinical conditions presented during the ICU stay and outcomes. The information about the patients was obtained through daily direct observations and daily reading of the records of the care team professionals in the patients' medical records.

Each patient was directly observed by the research team at more than one time of day (morning and afternoon), considering whether he was resting at bed, or was being 
mobilized in bed, transferred from bed to armchair, from the armchair to the bed, or wandered about. Variables related to the previous and current health history, mortality risk, and severity of patients on ICU admission were assessed using the Simplified Acute Physiology Score 3 $(\text { SAPS III) })^{(14-15)}$ to the use of drugs and devices, care demand, patient relationship by nursing professional, each of the domains of the Morse scale ${ }^{(8)}$ and its overall score ${ }^{(7)}$, risk assessment for developing pressure injury by applying the Braden Scale ${ }^{(16-17)}$, in addition to other variables that could be associated with falls.

For purposes of sample calculation, we used those from the Risk Management Commission of the institution hosting the study, which indicate the maximum incidence of two adverse events/day in the ICU. Considering a power of $80 \%$ and a significance level of $5 \%$, the need to include 5,298 observations was estimated. Data was entered and analyzed using the SPSS v.20.0 software. The normality for the distribution of the continuous variables was tested using the Shapiro-Wilk test. A descriptive data analysis was performed, respecting the characteristics and distribution of the variables, representing them by mean values \pm standard deviation, median and interquartile range, or absolute numbers and proportion, as indicated. The accumulated incidence and fall incidence density were calculated. The analysis was restricted to the description of the determinants, not using univariate and multivariate analytical statistics, due to the low number of events (falls).

The project was approved for its ethical and methodological aspects by the Institution's Research Ethics Committee on 05/14/2018 (CAE: 83455618.3.0000.5530). The Free and Informed Consent Form was applied to the research participants and/or to the relative responsible for the hospitalization.

\section{RESULTS}

From June to October 2018,673 potentially eligible patients were admitted. Of these, 551 patients were included, totaling 7,839 observations. Figure 1 shows the flowchart with the inclusion data and the reasons for the exclusion of the patients in the study.

\section{Characterization of the sample}

The sample was constituted, in its majority, by men, with a mean age of 60 years old. The median Morse Scale score was 50 [15 - 105], of which 484 (87.8\%) patients scored 50 at high risk for falls, and 38 (6.9\%) scored 35 at medium fall. The other sample characterization data are described in Table 1.

\section{Density of falls}

In the 7,839 observations, four falls were identified. The estimated incidence of falls is 5.1/10,000 observations/day with a $99 \%$ confidence interval [0.9 to 16]. Considering the patient's length of stay in the ICU at 6 [3 - 12.7] days, the fall incidence density is $7 / 10,000$ observations/day with a $99 \%$ confidence interval [1,2 to 22].

\section{Description of the characteristics of the patients with falls}

Of the 551 patients who participated in the study, 228 were mobilized at some time during hospitalization. Of the four patients who experienced falls during follow-up, most were men (75\%) with a mean age of 61 years old.

These four patients were seated in the armchair at the time of the fall, 3 of them (75\%) had no mechanical restraint

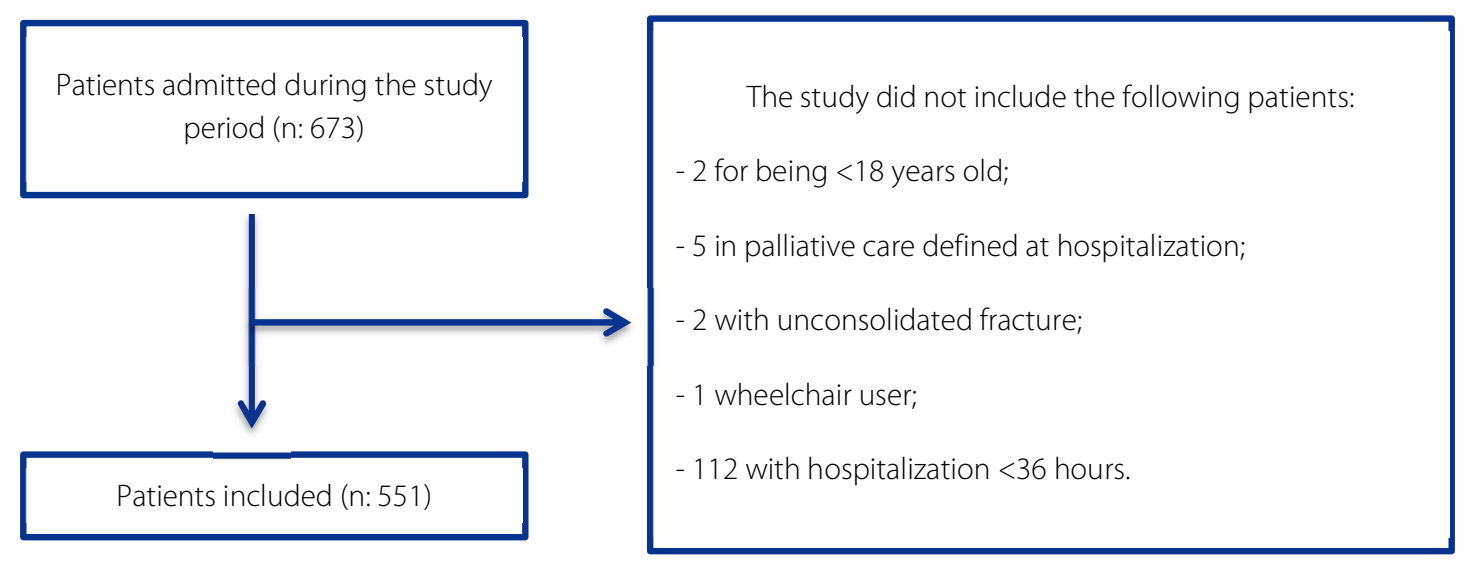

Figure 1 - Research flowchart with eligibility data. Porto Alegre/RS, Brazil, 2018 
Table 1 - Sociodemographic and clinical characteristics of the patients. Porto Alegre/RS, Brazil, 2018

Variables $\mathbf{n}=\mathbf{5 5 1}$

Male gender (\%)

$327(59.3 \%)$

Age (years old)*

Value of the Simplified Acute Physiology Score 3 (SAPS 3) upon admission*

Morse value on admission ${ }^{\dagger}$

\section{Braden value on admission}

\begin{tabular}{l} 
Braden 11 \\
Braden 10 \\
\hline Braden 13
\end{tabular}

\section{ICU length of stay in days ${ }^{\dagger}$}

Hospitalization type in the ICU (\%)

Clinical

Surgical

\section{Patients origin units}

\begin{tabular}{lr} 
Surgical block & $197(35.8 \%)$ \\
\hline Emergency & $171(31 \%)$ \\
\hline Hospitalization units & $183(33.2 \%)$
\end{tabular}

$340(61.7 \%)$

$211(38.3 \%)$
297 (53.9\%)

$73(13.2 \%)$

$38(6.9 \%)$

$6[3-12.7]$

\section{Reason for ICU admission}

Postoperative major surgery

$192(34.8 \%)$

Acute respiratory distress

$182(33 \%)$

Septic shock

$47(8.5 \%)$

Other reasons

$130(23.7 \%)$

\section{Comorbidities}

\begin{tabular}{lc}
\hline SAH & $278(50.5 \%)$ \\
\hline DM 2 & $155(28.1 \%)$ \\
\hline Neoplasia & $135(24.5 \%)$ \\
\hline Pressure injury on arrival at the ICU & $183(33.3 \%)$ \\
\hline Clinical outcome (\%) & $163(29.6 \%)$ \\
\hline Death & $388(70.4 \%)$ \\
\hline ICU discharge
\end{tabular}

Source: Research data, 2018

*Continuous variables expressed as mean value \pm standard deviation; categorical variables expressed as $n$ (\%); †asymmetric variables presented as median and interquartile range. 
and two patients (50\%) had a footrest. None of the patients were on sedative, analgesic or vasoactive drugs in the last 24 hours prior to the fall and all had a negative evaluation for delirium. Two patients (50\%) were under precaution of contact isolation due to an isolated multiresistant germ.

Two of the falls occurred over the weekend, when there is a higher patient-worker relationship, with 3 (75\%) patients being cared for by a technician who also cared for another patient and 2 (50\%) of them were being cared for by a nurse who also took care of another 5 patients.

Despite the fall, there was no serious harm to any of the patients. In addition, no accidental invasive device removal was observed, only 1 (25\%) patient had central venous catheter traction. Table 2 displays in detail the characteristics of the patients who were mobilized during the study and who displayed a fall or not.

Table 2 - Description of the characteristics of the mobilized patients who displayed a fall and those who did not. Porto Alegre/RS, Brazil, 2018

\begin{tabular}{lcc} 
Variables & Fall & Not fall \\
$\mathrm{n}(\%)$ & $4(100)$ & $224(100)$ \\
\hline Male gender $(\%)$ & $3(75 \%)$ & $129(57.6 \%)$ \\
\hline Age (years old)* & $61 \pm 26$ & $60.9 \pm 15.5$ \\
\hline SAPS 3 value on admission* & $72 \pm 14.6$ & $60.8 \pm 17.9$ \\
\hline Morse value on admission* $^{*}$ & $56.2 \pm 12.5$ & $49.7 \pm 7.2$ \\
\hline Braden value on admission $^{*}$ Braden 10 & $2(50 \%)$ & $25(11.2 \%)$ \\
\hline Braden 11 & $1(25 \%)$ & $118(52.7 \%)$ \\
\hline Braden 13 & $1(25 \%)$ & $23(10.3 \%)$ \\
\hline Time of permanence in the ICU in days $\dagger$ & $4.5[3.2-6.5]$ & $6[3-12.7]$ \\
\hline
\end{tabular}

\section{Hospitalization type in the ICU (\%)}

\begin{tabular}{lll}
\hline Clinical & $2(50 \%)$ & $340(61.7 \%)$ \\
\hline Surgical & $2(50 \%)$ & $211(38.3 \%)$ \\
\hline
\end{tabular}

Patients origin units

\begin{tabular}{lll}
\hline Surgical block & $2(50 \%)$ & $119(53.1 \%)$ \\
\hline Emergency & $2(50 \%)$ & $48(21.4 \%)$ \\
\hline
\end{tabular}

\section{Reason for ICU admission}

\begin{tabular}{lcr}
\hline Postoperative major surgery & $2(50 \%)$ & $118(52.6 \%)$ \\
\hline Acute respiratory distress & $1(25 \%)$ & $54(24.1 \%)$ \\
\hline Post-PCR & $1(25 \%)$ & $7(3.1 \%)$ \\
\hline Other causes & - & $45(20.2 \%)$
\end{tabular}

\section{Comorbidities}

\begin{tabular}{llr}
\hline SAH & $2(50 \%)$ & $121(54 \%)$ \\
\hline Neoplasia & $2(50 \%)$ & $64(28.6 \%)$ \\
\hline DM 2 & $1(25 \%)$ & $59(26.3 \%)$ \\
\hline
\end{tabular}


Table 2 - Cont.

\section{Variables}

Pressure injury on arrival at the ICU
Fall

$2(50 \%)$
Not fall

$183(33.3 \%)$

\section{Clinical outcome (\%)}

ICU discharge

$4(100 \%)$

$208(92.9 \%)$

Source: Research data, 2018

*Continuous variables expressed as mean value \pm standard deviation; categorical variables expressed as $n(\%)$; ${ }^{\dagger}$ asymmetric variables presented as median and interquartile range.

\section{口DISCUSSION}

In this study, we found that falls are infrequent in intensive care settings. Studies on ICU falls are rare ${ }^{(10)}$ and, among those published, it is possible to observe less robust designs that were directed to case reports and to the evaluation of predisposing factors to falls. As previously shown ${ }^{(2-4)}$, the incidence of falls may vary according to the patient's profile, clinical moment during hospitalization, as well as the characteristics of the evaluated institutions. According to the authors, from a broad assessment, the incidence of falls can range from 1.3 to 13.0 per 1,000 patients a day ${ }^{(18-19)}$, figures much higher than those presented in this research.

Regarding the conditions that could be associated with falls, our results show that they occur at times when patients had no sensory fluctuation and were sitting in the armchair, but without additional safety measures, such as mechanical restraint. As this is a multi-factorial event, the need for periodic and individual assessment of the risk factors for falls by the team to plan their prevention is reaffirmed ${ }^{(5)}$.

The Morse scale, although widely used for ICU patients, seems to be little discriminatory of practical actions to be implemented in the care. As we have seen, there were no substantial differences between the scale values for the patients who fell and for those who did not fall; almost all patients achieved a moderate to high risk score. Falls are reaffirmed as multi-factorial(20), with a strong influence of individual characteristics to each patient as a major factor for a higher or lower risk estimate. New studies, even if not developed in intensive care, bring out the need for evaluating intrinsic and extrinsic factors ${ }^{(13,20)}$. A better understanding of the predisposing factors for falls in specific care contexts allows, in addition to understanding the phenomenon, the search for more individualized risk stratification measures, as well as the institution of own interventions ${ }^{(13)}$. These discussions make us reflect on the real utility of maintaining the use of the Morse Scale in the caring for critically ill patients.

Additionally, although preliminarily, the present study suggests that patient mobilization is not an important factor in the risk of falls with harm to critically ill patients, which may support that more patients benefit from the favorable clinical outcomes of mobilization. Corroborating this finding, a retrospective longitudinal study that evaluated the safety of mobilizing critically ill patients with the intervention of a specialized team and that had falls as one of the evaluated indicators, the researchers concluded that mobilization, besides bringing benefits in hard outcomes, it is also a safe practice ${ }^{(21)}$. Also, a recent cross-sectional study aimed at assessing knowledge about early mobilization (EM) in critically ill patients found that most nursing staff professionals agree that the benefits associated with EM outweigh the risks for patients on mechanical ventilation ${ }^{(22)}$.

Although this study included a large number of patients, followed up for many days, thus generating a large number of observations, the low number of events (falls) limited the use of more robust statistical methods, with modeling to adjust for confounding factors. We are therefore restricted to reporting the cases. Even so, this study contributes to generate discussion about the need to use the Morse scale in the ICUs, since nurses are involved in this process, but the information does not change the care plan for the patient.

\section{CONCLUSION}

The fall event is rare in ICUs, which can be explained by the use of safe care practices. It is believed that the Morse value attributed on ICU admission is overestimated, since the scale is not validated for this patient profile, not assisting the professional in the implementation of individualized safety measures.

Among the events, it was observed that they occurred while the patient was mobilized in the armchair, without the use of additional safety precautions such as mechanical restraint and footrest, although they presented a high risk for falls according to the Morse scale score. All the events herein displayed were free from harm to patients and are not understood as a factor contrary to the mobilization of the critical patient.

Despite having a large number of observations, as this is a rare event, it was not possible to employ a more robust statistical analysis, which limited the submission of the results to be performed descriptively. Even so, it is believed that the 
discussion about the subject is relevant so that, through the knowledge of the incidence of the events, they can be investigated with a view to identifying factors associated with falls and the subsequent adoption of individualized measures to prevent them.

There are contributions from the findings of this study that have relevance to research and teaching, as it enables criticality in the indiscriminate use of scales, especially the Morse one, and indeed this may be aggregated to it for a safe and qualified care. It is also cited the advance of scientific knowledge on the subject little addressed for the training of new professionals, as it encourages rethinking the care practices and also the proposition of new research on the topic.

\section{REFERENCES}

1. Ministério da Saúde (BR). Anexo 1: Protocolo Prevenção de Quedas. Braślia (DF): Ministério da Saúde, Anvisa, Fiocruz; 2014 [cited 2019 Jul 13]. Available from: https://www20.anvisa.gov.br/segurancadopaciente/index.php/publicacoes/ item/prevencao-de-quedas

2. Healey F, Scobie S, Oliver D, Pryce A, Thomson R, Glampson B. Falls in English and Welsh Hospitals: a national observational study based on retrospective analysis of 12 months of patient safety incident reports. Qual Saf Health Care. 2008;17(6):424-30. doi: https://doi.org/10.1136/qshc.2007.024695

3. Dunton N, Gajewski B, Taunton RL, Moore J. Nurse staffing and patient falls on acute care hospital units. Nurs Outlook. 2004;52(1):53-9. doi: https://doi. org/10.1016/j.outlook.2003.11.006

4. Oliver D, Healey F, Haines TP. Preventing falls and fall-related injuries in hospitals. Clin Geriatr Med. 2010;26(4):645-92. doi: https://doi.org/10.1016/j. cger.2010.06.005

5. Barbosa AS, Chaves EHB, Ribeiro RG, Quadros DV, Suzuki LM, Magalhães AMM. Characterization of the adult patients' falling incidents in a university hospital. Rev Gaúcha Enferm. 2019;40(esp):e20180303. doi: https://doi. org/10.1590/1983-1447.2019.20180303

6. Costa-Dias MJM, Ferreira PL. Escalas de avaliação de risco de quedas. Rev Enf Ref. 2014;4(2):153-61. doi: https://doi.org/10.12707/RIII12145

7. Morse JM, Tylko SJ, Dixon HA. Characteristics of the fall-prone patient. Gerontologist. 1987;27(4):516-22. doi: https://doi.org/10.1093/ geront/27.4.516

8. Urbanetto JS, Creutzberg M, Franz F, Ojeda BS, Gustavo AS, Bittencourt HR et al. Morse Fall Scale: translation and transcultural adaptation for the portuguese language. Rev Esc Enferm USP. 2013;47(3):569-75. doi: https://doi. org/10.1590/50080-623420130000300007

9. Morse, J. Preventing patients falls: Establishing a fall intervention program. $2^{\text {nd }}$ ed. New York: Springer Publishing Company; 2009.
10. Oliveira AC, Garcia PC, Nogueira LS. Nursing workload and occurrence of adverse events in intensive care: asystematicreview. Rev Esc Enferm USP.2016;50(4):67989. doi: https://doi.org/10.1590/50080-623420160000500020

11. Decesaro MN, Padilha KG. latrogenia na assistência de enfermagem durante internação em UTI: queda de pacientes. Rev Ciênc Cuidado Saúde. 2002 [citado 2019 abr 10]; 1(1):159-62. Disponível em: http://periodicos.uem.br/0js/index. php/CiencCuidSaude/article/view/5688

12. Meneguin, S, Ayres, JA, Bueno GH. Caracterização das quedas de pacientes em hospital especializado em cardiologia. REUFSM. 2014;4(4):784-91. doi: https:// doi.org/10.5902/2179769213554

13. Severo IM, Kuchenbecker R, Vieira DFVB, Lucena AF, Almeida MA. Risk factors for fall occurrence in hospitalized adult patients: a case-control study. Rev Latino-Am Enfermagem. 2018;26:e3016. doi: https://doi.org/10.1590/15188345.2460.3016

14. Metnitz $P G$, Moreno RP, Almeida E, Jordan B, Bauer P, Campos RA, et al. SAPS3 - from evaluation of the patient to evaluation of the intensive care unit. Part 1: Objectives, methods and cohort description. Intensive Care Med. 2005;31(10):1336-44. doi: https://doi.org/10.1007/s00134-005-2763-5

15. Moreno RP, Metnitz PG, Almeida E, Jordan B, Bauer P, Campos RA, et al. SAPS 3 - from evaluation of the patient to evaluation of the intensive care unit. Part 2: Development of a prognostic model for hospital mortality at ICU admission. Intensive Care Med. 2005;32(5):1345-55. doi: https://doi.org/10.1007/ s00134-005-2763-5

16. Braden B, Bergstrom N. A Conceptual schema for the study of the etiology of pressure sores. Rehabilit Nurs. 2000;25(3):105-10. doi: https://doi. org/10.1002/j.2048-7940.2000.tb01879.x

17. Paranhos WY, Santos VLCG. Avaliação de risco para úlceras de pressão por meio da escala de Braden, na língua portuguesa. Rev Esc Enferm USP. 1999 [cited 2019 Apr 20];33(esp):191-206. Available from: http://www.ee.usp.br/reeusp/ upload/pdF/799.pdF

18. Word Health Organization (CH). WHO Global report on falls prevention in older age. Geneva: WHO; 2007 [cited 2019 Apr 20]. Available from: https://www. who.int/ageing/publications/Falls_prevention7March.pdf

19. National Patient Safety Agency (UK). Slips trips and falls in hospital: the third report from the Patient Centre Observatory. London: NPSA; 2007 [cited 2019 Apr 20]. Available from: https://www.slips-online.co.uk/resources/slips-tripsand-falls-in-hospital-summary.pdf

20. Resnick B. Learning from our history: prevention of falls in acute care. Geriatr Nurs. 2015;36(5):339-40. doi: https://doi.org/10.1016/j.gerinurse.2015.08.002

21. Fraser D, Spiva L, Forman W, Hallen C. Original Research: Implementation of on early mobility program in an ICU. Am J Nurs. 2015;115(12):49-58. doi: https:// doi.org/10.1097/01.NAJ.0000475292.27985.fC

22. Fontela PC, Forgiarini LAJ, Friedman G. Clinical attitudes and perceived barriers to early mobilization of critically ill patients in adult intensive care units. Rev Bras Ter Intensiva. 2018;30(2):187-94. doi: https://doi.org/10.5935/0103507X.20180037

\section{- Corresponding author:}

Andréia Martins Specht

E-mail: spechtandreia@gmail.com

\section{Associate editors: \\ Cecília Helena Glanzner}

Received: 05.16.2019

Approved: 08.29.2019

\section{Editor-in-chief:}

Maria da Graça Oliveira Crossetti 